\title{
Novel resveratrol analogs induce apoptosis and cause cell cycle arrest in HT29 human colon cancer cells: Inhibition of ribonucleotide reductase activity
}

\author{
PHILIPP SAIKO $^{1}$, MICHAEL PEMBERGER ${ }^{1}$, ZSUZSANNA HORVATH $^{1}$, \\ IVO SAVINC $^{1}$, MICHAEL GRUSCH ${ }^{2}$, NORBERT HANDLER $^{3}$, THOMAS ERKER ${ }^{3}$, \\ WALTER JAEGER $^{3}$, MONIKA FRITZER-SZEKERES ${ }^{1}$ and THOMAS SZEKERES ${ }^{1}$ \\ ${ }^{1}$ Clinical Institute of Medical and Chemical Laboratory Diagnostics, Medical University of Vienna, \\ Waehringer Guertel 18-20; ${ }^{2}$ Department of Medicine I, Institute of Cancer Research, Medical \\ University of Vienna, Borschkegasse $8 \mathrm{a} ;{ }^{3}$ Department of Clinical Pharmacy and Diagnostics, \\ Faculty of Life Sciences, University of Vienna, Althanstrasse 14, A-1090 Vienna, Austria
}

Received November 19, 2007; Accepted February 20, 2008

\begin{abstract}
Resveratrol (3,4',5-trihydroxy-trans-stilbene; RV), an ingredient of wine, exhibits a broad spectrum of antiproliferative effects against human cancer cells. In order to enhance these effects, we modified the molecule by introducing additional methoxyl and hydroxyl groups. The resulting novel RV analogs, M5 (3,4',5-trimethoxy-trans-stilbene), M5A (3, 3',4,5'-tetramethoxy-trans-stilbene) and M8 $\left(3,3^{\prime}, 4,4^{\prime}, 5,5^{\prime}\right.$-hexahydroxy-trans-stilbene) were investigated in HT29 human colon cancer cells. Cytotoxicity was evaluated by clonogenic assays and the induction of apoptosis was determined using a specific Hoechst/propidium iodide double staining method. Cell cycle distribution was evaluated by FACS. The influence of M8 on the concentration of deoxyribonucleoside triphosphates (dNTPs), the products of ribonucleotide reductase (RR), was determined by highperformance liquid chromatography. M5 and M5A caused a dose-dependent induction of apoptosis and led to remarkable changes of the cell cycle distribution. After treatment with M5, growth arrest occurred mainly in the G2-M phase, whereas incubation with M5A resulted in arrest in the G0-G1 phase of the cell cycle. Incubation of HT29 cells with M8 produced a significant imbalance of intracellular dNTP pools, being
\end{abstract}

Correspondence to: Professor Thomas Szekeres, Clinical Institute of Medical and Chemical Laboratory Diagnostics, General Hospital of Vienna, Medical University of Vienna, Waehringer Guertel 18-20, A-1090 Vienna, Austria

E-mail: thomas.szekeres@meduniwien.ac.at

Key words: colon cancer, resveratrol, 3,4',5-trimethoxy-transstilbene, 3,3',4,5'-tetramethoxy-trans-stilbene, 3,3',4,4',5,5'-hexahydroxy-trans-stilbene, apoptosis, cell cycle arrest, ribonucleotide reductase synonymous with the inhibition of RR activity. The dATP pools were abolished, whereas the dCTP and dTTP pools increased. Due to these promising results, the investigated $\mathrm{RV}$ analogs deserve further preclinical and in vivo testing.

\section{Introduction}

Resveratrol (3,4',5-trihydroxy-trans-stilbene; RV; Fig. 1) is a polyphenol and has been classified as a phytoalexin as it is synthesized in spermatophytes in response to injury, UV irradiation and fungal attack (1). It was first isolated in 1940 as an ingredient of the roots of white hellebore (Veratrum grandiflorum $O$. Loes) and has since been found in a wide variety of $\sim 70$ plant species, including grapes, mulberries and peanuts (2). RV exhibits a remarkable inhibitory potential in the various stages of tumor development. The antitumor activity of RV was first shown by its ability to reduce the incidence of the carcinogen-induced development of cancers in experimental animals (3). Subsequently, RV has been shown to exert numerous effects that may block tumor development at several discrete stages during the multigenic process of carcinogenesis (4), involving interactions between RV and manifold targets $(5,6)$. These targets include kinases $(7,8)$, steroid hormone receptors (9-11), reactive oxygen species $(6,12)$, ribonucleotide reductase $(13,14)$ and DNA polymerases (15). RV causes arrest at the $\mathrm{S} / \mathrm{G} 2$ phase transition of the cell cycle (16) and is capable of inducing differentiation and apoptosis in a multitude of human tumor cell lines, such as leukemia, colon, breast, prostate and esophageal cells $(11,17-21)$. RV has been identified as an effective inhibitor of ribonucleotide reductase (RR) which catalyzes the ratelimiting step of de novo DNA synthesis, namely the reduction of ribonucleotides into the corresponding deoxyribonucleoside triphosphates (dNTPs) $(13,14)$. This was substantiated by its effect on the significant decrease of the four intracellular dNTP concentrations, the products of RR. RV treatment had a differential effect on dNTP pools, with dATP and dGTP concentrations showing the greatest 
decrease (22). The RV inhibition of ribonucleotide reductase is based on its ability to scavenge the tyrosyl radical on the R2 subunit of ribonucleotide reductase, which is essential for its function (14). Other clinically established inhibitors of $\mathrm{RR}$, such as hydroxyurea or fludarabine are applied successfully in combination chemotherapy regimens for the treatment of leukemia.

The importance of all these targets for cancer development is well-known and therefore RV can beneficially contribute to cancer prevention. Since the identification of RV health benefits are largely owed to its high abundance in certain plants and foods, the discovery of further naturally occurring stilbenes, as well as chemically modified analogs that are superior to RV in their cancer chemopreventive properties, may be expected.

In this context, we prepared a series of hydroxylated and methoxylated RV analogs with the aim of identifying new agents with potential clinical relevance and establishing a structure- and anticancer-activity relationship. The antitumor effects of M5 (3,4',5-trimethoxy-trans-stilbene), M5A (3,3',4,5'-tetramethoxy-trans-stilbene), and M8 (3,3',4,4',5,5'hexahydroxy-trans-stilbene) are presented herein. The activity of these new compounds was tested in HT29 human colon cancer cells. Their cytotoxicity was evaluated by clonogenic assays and the induction of apoptosis was determined by employing a specific Hoechst/propidium iodide double staining method. Cell cycle distribution after exposure to M5 and M5A was investigated by FACS analysis. Since we showed earlier that M8 causes a significant imbalance of intracellular dNTP concentrations in HL-60 cells (23), we now investigated whether M8 had comparable effects on the dNTP pools in HT29 cells.

\section{Materials and methods}

Chemicals and supplies. M5 (3,4',5-trimethoxy-transstilbene), M5A (3,3',4,5'-tetramethoxy-trans-stilbene) and M8 (3,3',4,4', 5, 5'-hexahydroxy-trans-stilbene) were synthesized as previously described (24) and provided by the Department of Clinical Pharmacy and Diagnostics, Faculty of Life Sciences, University of Vienna, Austria. The structural formulas are shown in Fig. 1. RV and the other chemicals and reagents were commercially available (Sigma-Aldrich, Vienna, Austria) and of the highest purity.

Cell culture. The HT29 human colon cancer cell line was purchased from ATCC (American Type Culture Collection, Manassas, VA, USA). Cells were grown in RPMI-1640 medium supplemented with $10 \%$ heat-inactivated fetal calf serum (FCS) and $1 \%$ penicillin-streptomycin in a humidified atmosphere containing $5 \% \mathrm{CO}_{2}$. The media and supplements were obtained from Life Technologies (Paisley, Scotland, UK). Cell counts were determined using a micro cellcounter CC-108 (Sysmex, Kobe, Japan). Cells in the logarithmic phase of growth were used for the experiments described below.

Clonogenic assay. Cells ( $1 \times 10^{3} /$ well) were plated in $24-$ well plates and allowed to attach overnight at $37^{\circ} \mathrm{C}$ in a humidified $5 \% \mathrm{CO}_{2}$ atmosphere. After $24 \mathrm{~h}$, the medium was
A

RV<smiles>Oc1ccc(/C=C/c2cc(O)cc(O)c2)cc1</smiles>

B

M5<smiles>COc1ccc(/C=C/c2cc(OC)cc(OC)c2)cc1</smiles>

C

M5A<smiles>COc1cc(/C=C/c2ccc(OC)c(OC)c2)cc(OC)c1</smiles>

D<smiles>Oc1cc(/C=C/c2cc(O)c(O)c(O)c2)cc(O)c1O</smiles>

Figure 1. The structural formulas of RV, M5, M5A and M8 including the nomenclature, molecular weight and empirical formula. (A) 3,4',5Trihydroxy-trans-stilbene $\mathrm{C}_{14} \mathrm{H}_{12} \mathrm{O}_{3}, \mathrm{MW}=228.25$. (B) 3,4',5-Trimethoxytrans-stilbene $\mathrm{C}_{17} \mathrm{H}_{18} \mathrm{O}_{3}$, $\mathrm{MW}=270.33$. (C) 3,3',4,5'-Tetramethoxy-transstilbene $\mathrm{C}_{18} \mathrm{H}_{20} \mathrm{O}_{4}, \mathrm{MW}=300.36$. (D) $3,3^{\prime}, 4,4^{\prime}, 5,5^{\prime}$-Hexahydroxy-transstilbene $\mathrm{C}_{14} \mathrm{H}_{12} \mathrm{O}_{6}, \mathrm{MW}=276.25$.

removed and replaced by a fresh medium containing the designated concentration of the drugs. The plates were then incubated for 7 days. Subsequently, the medium was carefully removed from the wells and the plates were stained with $0.5 \%$ crystal violet solution for $5 \mathrm{~min}$. Colonies of $>50$ cells were counted using an inverted microscope at 40-fold magnification. All of the experiments were performed in triplicate and repeated three times.

Hoechst dye 33258 and propidium iodide double staining. Hoechst staining was performed according to the method described by Grusch and coworkers (25). Cells $\left(0.1 \times 10^{6} / \mathrm{ml}\right)$ were seeded in $25 \mathrm{~cm}^{2}$ Nunc tissue culture flasks, allowed to adhere overnight and exposed to increasing concentrations of drugs for 72 h. Hoechst 33258 (HO, Sigma, St. Louis, MO, USA) and propidium iodide (PI, Sigma) were added directly to the cells at final concentrations of 5 and $2 \mu \mathrm{g} / \mathrm{ml}$, respectively. After $60 \mathrm{~min}$ of incubation at $37^{\circ} \mathrm{C}$, cells were examined on a Leica DMR XA fluorescence microscope (Leica, Wetzlar, Germany) equipped with appropriate filters for Hoechst 33258 and PI. This method is used to distinguish between early and late apoptosis, and necrosis. Cells were judged according to their morphology and the integrity of their 
cell membranes, which can easily be seen after propidium iodide staining. Cells were counted under the microscope and the number of apoptotic cells was given as a percentage value.

Cell cycle distribution analysis. Cells $\left(0.4 \times 10^{6} / \mathrm{ml}\right)$ were seeded in $25 \mathrm{~cm}^{2}$ Nunc tissue culture flasks, allowed to adhere overnight and incubated with increasing concentrations of drugs at $37^{\circ} \mathrm{C}$ under cell culture conditions. After $24 \mathrm{~h}$, cells were harvested and suspended in $5 \mathrm{ml}$ cold PBS, centrifuged, re-suspended and fixed in $3 \mathrm{ml}$ cold ethanol (70\%) for $30 \mathrm{~min}$ at $4^{\circ} \mathrm{C}$. After two washing steps in cold PBS, RNase A and propidium iodide were added at a final concentration of $50 \mu \mathrm{g} / \mathrm{ml}$ each and incubated at $4^{\circ} \mathrm{C}$ for $60 \mathrm{~min}$ before measurement. Cells were analyzed on a FACSCalibur flow cytometer (BD Biosciences, San Jose, CA, USA) and cell cycle distribution was calculated with ModFit LT software (Verity Software House, Topsham, ME, USA).

Determination of deoxyribonucleoside triphosphates (dNTPs). Cells were seeded in $175 \mathrm{~cm}^{2}$ tissue culture flasks ( $4 \times 10^{7} /$ flask) for $24 \mathrm{~h}$ to ensure attachment and then incubated with increasing concentrations of M8 for another $24 \mathrm{~h}$. The cells were then centrifuged at $1800 \mathrm{~g}$ for $5 \mathrm{~min}$, re-suspended in $100 \mu 1$ of PBS and extracted with $10 \mu \mathrm{l}$ of trichloracetic acid (90\%). The lysate was allowed to rest on ice for $30 \mathrm{~min}$ and neutralized by the addition of 1.5 volumes of freon containing $0.5 \mathrm{~mol} / \mathrm{l}$ tri-noctylamin. Concentrations of dNTPs were then determined using the method described by Garrett and Santi (26). Aliquots $(120 \mu \mathrm{l})$ of the sample were analyzed using a Merck 'La Chrom' high-performance liquid chromatography (HPLC) system (Merck, Darmstadt, Germany) equipped with D-7000 interface, L-7100 pump, L-7200 autosampler and L-7400 UV detector. Detection time was set at $80 \mathrm{~min}$, with the detector operating on $280 \mathrm{~nm}$ for $40 \mathrm{~min}$ and then switched to $260 \mathrm{~nm}$ for another $40 \mathrm{~min}$. Samples were eluted with a $3.2 \mathrm{M}$ ammonium phosphate buffer $(\mathrm{pH} 3.6$, adjusted by the addition of $3.2 \mathrm{mM} \mathrm{H}_{3} \mathrm{PO}_{4}$ ) containing $20 \mathrm{M}$ acetonitrile using a 4.6x250 mm Partisil 10 SAX column (Whatman Ltd., Kent, UK). Separation was performed at a constant ambient temperature and a flow rate of $2 \mathrm{ml} / \mathrm{min}$. The concentration of each dNTP was calculated as a percentage of the total area under the curve for each sample.

Statistical analysis. Dose-response curves, tables and statistical significance were calculated and graphically represented using Prism 4.03 software (GraphPad, San Diego, CA, USA).

\section{Results}

Effect of drugs on the growth of HT29 cell colonies. Cells were treated with increasing concentrations of drugs and colonies were counted after 7 days of incubation as described in Materials and methods. M5, M5A and M8 inhibited the growth of HT29 cell colonies with $\mathrm{IC}_{50}$ values of $1.25,15$ and $8 \mu \mathrm{M}$, respectively, whereas RV yielded an $\mathrm{IC}_{50}$ value of $7 \mu \mathrm{M}$. The results are shown in Fig. 2.

Induction of apoptosis in HT29 cells. HT29 cells were incubated with increasing concentrations of M5 or M5A for $72 \mathrm{~h}$. The cells were then double stained with Hoechst 33258

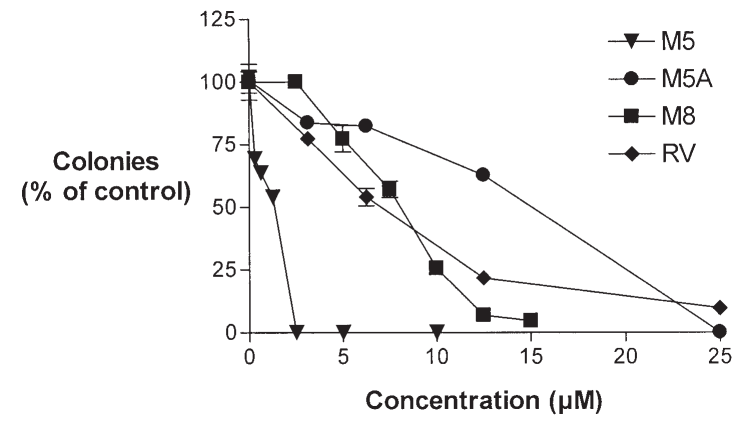

Figure 2. The growth inhibition of HT29 cell colonies after treatment with RV, M5, M5A and M8 for 7 days. Cells ( $1 \times 10^{3} /$ well) were plated in 24-well plates and allowed to attach overnight at $37^{\circ} \mathrm{C}$ in a humidified $5 \% \mathrm{CO}_{2}$ atmosphere. After $24 \mathrm{~h}$, the medium was removed and replaced by a fresh medium containing the designated concentration of the drugs. The plates were then incubated for 7 days. Subsequently, the medium was carefully removed from the wells and the plates were stained with $0.5 \%$ crystal violet solution for $5 \mathrm{~min}$. Colonies of $>50$ cells were counted using an inverted microscope at 40-fold magnification.

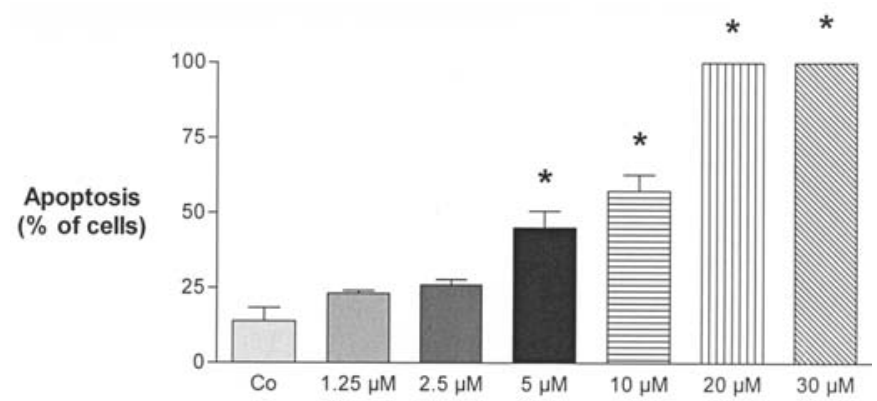

Figure 3. The induction of apoptosis in HT29 cells after incubation with M5 for $72 \mathrm{~h}$. Cells $\left(0.1 \times 10^{6} / \mathrm{ml}\right)$ were seeded in $25 \mathrm{~cm}^{2}$ Nunc tissue culture flasks, allowed to adhere overnight and exposed to increasing concentrations of drugs for $72 \mathrm{~h}$. Hoechst 33258 and propidium iodide were added directly to the cells at final concentrations of 5 and $2 \mu \mathrm{g} / \mathrm{ml}$, respectively. After $60 \mathrm{~min}$ of incubation at $37^{\circ} \mathrm{C}$, the cells were examined on a Leica DMR XA fluorescence microscope equipped with appropriate filters for Hoechst 33258 and PI. The cells were counted under the microscope and the number of apoptotic cells was given as a percentage value. ${ }^{*} \mathrm{p}<0.05$, values significantly different from the control.

and propidium iodide as described in Materials and methods. After the incubation period, the morphology of HL-60 cells showed nuclear condensation and fragmentation (early apoptosis) as well as signs of late apoptosis with membrane damage and incorporation of propidium iodide. As shown in Fig. 3, the induction of apoptosis was dose-dependent with up to $100 \%$ of the cells showing hallmarks of apoptosis at $20 \mu \mathrm{M}$ M5. Treatment with $30 \mu \mathrm{M}$ M5A resulted in $95 \%$ apoptotic cells (Fig. 4).

Cell cycle distribution in HT29 cells. HT29 cells were prepared as described in Materials and methods and incubated with increasing concentrations of M5 or M5A for $24 \mathrm{~h}$. After treatment with $20 \mu \mathrm{M}$ M5, the growth arrest occurred mainly in the G2-M phase, increasing the cell population from 18.5 to $43.5 \%$. Simultaneously, cells in the G0-G1 phase decreased from 57.5 to $29.5 \%$. In contrast, the growth arrest after treatment with $100 \mu \mathrm{M}$ M5A occurred mainly in the G0-G1 


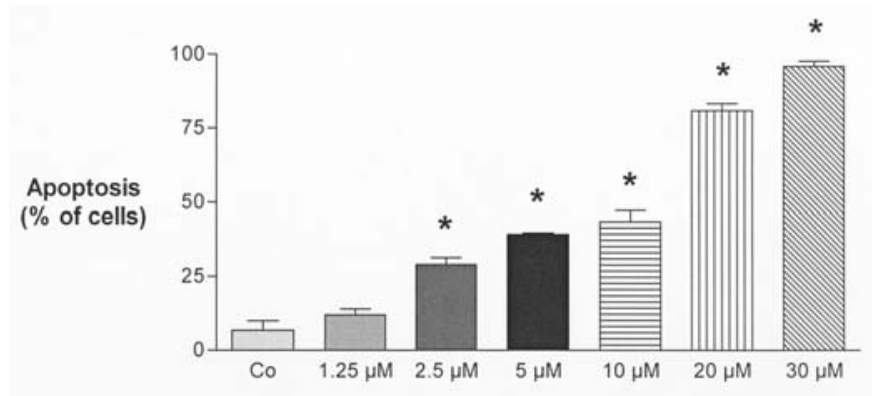

Figure 4. The induction of apoptosis in HT29 cells after incubation with M5A for $72 \mathrm{~h}$. Cells $\left(0.1 \times 10^{6} / \mathrm{ml}\right)$ were seeded in $25 \mathrm{~cm}^{2}$ Nunc tissue culture flasks, allowed to adhere overnight and exposed to increasing concentrations of drugs for $72 \mathrm{~h}$. Hoechst 33258 and propidium iodide were added directly to the cells at final concentrations of 5 and $2 \mu \mathrm{g} / \mathrm{ml}$, respectively. After $60 \mathrm{~min}$ of incubation at $37^{\circ} \mathrm{C}$, cells were examined on a Leica DMR XA fluorescence microscope equipped with appropriate filters for Hoechst 33258 and PI. The cells were counted under the microscope and the number of apoptotic cells was given as a percentage value. ${ }^{*} \mathrm{p}<0.05$, values significantly different from the control.

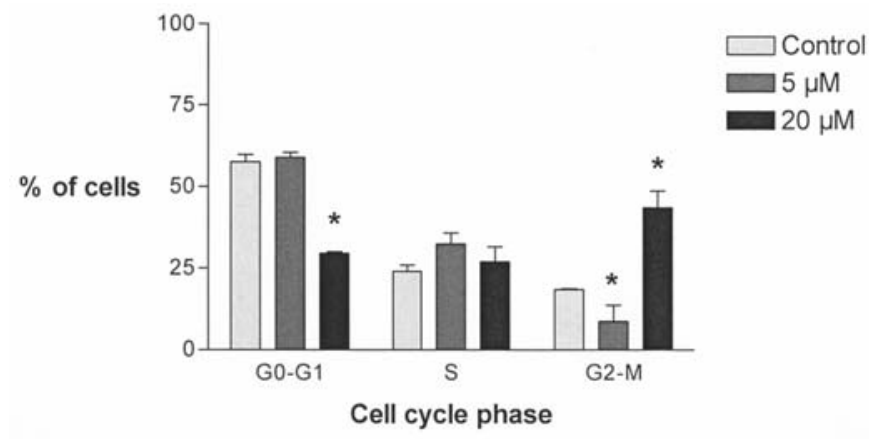

Figure 5. The cell cycle distribution in HT29 cells after incubation with M5 for $24 \mathrm{~h}$. Cells $\left(0.4 \times 10^{6} / \mathrm{ml}\right)$ were seeded in $25 \mathrm{~cm}^{2}$ Nunc tissue culture flasks, allowed to adhere overnight and incubated with increasing concentrations of drugs at $37^{\circ} \mathrm{C}$ under cell culture conditions. After $24 \mathrm{~h}$, the cells were harvested and suspended in $5 \mathrm{ml}$ cold PBS, centrifuged, resuspended and fixed in $3 \mathrm{ml}$ cold ethanol (70\%) for $30 \mathrm{~min}$ at $4^{\circ} \mathrm{C}$. After two washing steps in cold PBS, RNase A and propidium iodide were added at a final concentration of $50 \mu \mathrm{g} / \mathrm{ml}$ each and incubated at $4^{\circ} \mathrm{C}$ for $60 \mathrm{~min}$ before measurement. The cells were analyzed on a FACSCalibur flow cytometer (and cell cycle distribution was calculated with ModFit LT software). ${ }^{*} \mathrm{p}<0.05$, values significantly different from the control.

phase, increasing the cell population from 57.5 to $88 \%$. Simultaneously, the cells in the G2-M phase decreased from 18.5 to $4 \%$. The results are shown in Figs. 5 and 6.

Effect of M8 on the deoxyribonucleoside triphosphate (dNTP) pools in HT29 cells. HT29 cells were incubated with increasing concentrations of M8 for $24 \mathrm{~h}$. Then dNTP pool sizes were determined using the HPLC method described in Materials and methods. M8 treatment caused a remarkable imbalance of dNTPs in HT29 cells. The incubation of cells with 4 and $8 \mu \mathrm{M}$ M8 resulted in a significant depletion of intracellular dATP pools to 1.5 and $2 \%$ of controls, respectively. In contrast, treatment with $4 \mu \mathrm{M}$ M8 significantly increased the dCTP and dTTP pools to 167 and $223 \%$ of the control values, respectively. The dGTP pools remained beyond the detectability of the method. The results are shown in Fig. 7.

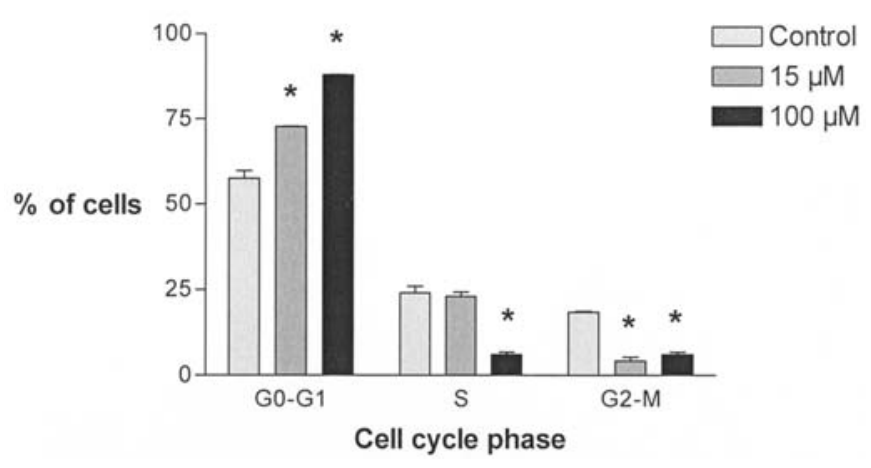

Figure 6. The cell cycle distribution in HT29 cells after incubation with M5A for $24 \mathrm{~h}$. Cells $\left(0.4 \times 10^{6} / \mathrm{ml}\right)$ were seeded in $25 \mathrm{~cm}^{2}$ Nunc tissue culture flasks, allowed to adhere overnight and incubated with increasing concentrations of drugs at $37^{\circ} \mathrm{C}$ under cell culture conditions. After $24 \mathrm{~h}$, the cells were harvested and suspended in $5 \mathrm{ml}$ cold PBS, centrifuged, resuspended and fixed in $3 \mathrm{ml}$ cold ethanol $(70 \%)$ for $30 \mathrm{~min}$ at $4^{\circ} \mathrm{C}$. After two washing steps in cold PBS, RNase A and propidium iodide were added at a final concentration of $50 \mu \mathrm{g} / \mathrm{ml}$ each and incubated at $4^{\circ} \mathrm{C}$ for $60 \mathrm{~min}$ before measurement. Cells were analyzed on a FACSCalibur flow cytometer (and cell cycle distribution was calculated with ModFit LT software). ${ }^{*} \mathrm{p}<0.05$, values significantly different from the control.

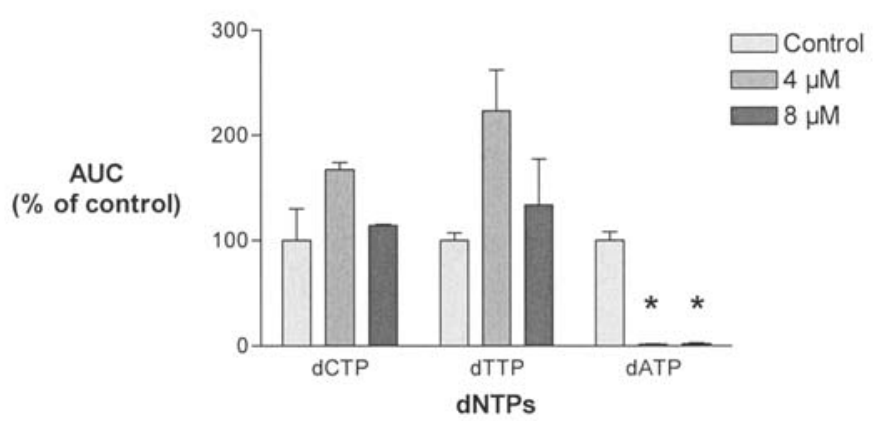

Figure 7. The concentration of dNTP pools in HT29 cells after treatment with M8 for $24 \mathrm{~h}$. Cells were seeded in $175 \mathrm{~cm}^{2}$ tissue culture flasks ( $\left.4 \times 10^{7} / \mathrm{flask}\right)$ for $24 \mathrm{~h}$ to ensure attachment and then incubated with increasing concentrations of M8 for another $24 \mathrm{~h}$. Afterwards, $5 \times 10^{7}$ cells were separated for the extraction of dNTPs. Concentrations of dNTPs were then determined using the method described by Garrett and Santi (26) and were calculated as a percent of the total area under the curve for each sample. ${ }^{*} \mathrm{p}<0.05$, values significantly different from the control.

\section{Discussion}

Resveratrol (3,4',5-trihydroxy-trans-stilbene; RV) is a naturally occurring polyphenolic compound found in grapes, wine and various medical plants. Numerous studies have shown that RV exerts remarkable antioxidant, anti-inflammatory and antitumor activities and demonstrates a preventive effect for cancer. RV was proven to inhibit ribonucleotide reductase (RR) which is the rate-limiting enzyme for de novo DNA synthesis and therefore considered an excellent target for cancer chemotherapy. Balanced deoxynucleosidetriphosphate (dNTP) concentrations are essential for DNA synthesis, especially in rapidly proliferating tumor cells. Various inhibitors of RR, such as hydroxyurea or difluorodeoxycytidine (Gemcitabine, $\mathrm{dFdC}$ ), are commonly used for the treatment of various human malignancies. 
In contrast to the detailed knowledge of RV activities in biological systems, little is known about the effects of other polyhydroxylated stilbenes. RV undergoes cytochrome P450 catalyzed hydroxylation to piceatannol (3,3',4',5-tetrahydroxytrans-stilbene; PCA) and two other unidentified mono- and dihydroxy-RV analogs. This demonstrates that a natural dietary cancer preventative agent can be converted to a compound with known chemopreventive and anticancer activity by the enzyme CYP1B1, which is overexpressed in a wide variety of human tumors.

In this context, we prepared a series of polyhydroxylated RV analogs with the aim of discovering new agents with potential clinical relevance. One of these derivatives is M8 (3,3',4,4',5,5'-hexahydroxy-trans-stilbene), which proved to be a potent inhibitor of RR, resulting in a significant alteration of the dNTP pool balance in HT29 cells. Due to this effect, DNA synthesis in rapidly growing cancer cells is blocked. M8 was already found to be a potent inhibitor of RR by causing a remarkable imbalance of the dNTP pools in HL-60 cells (23), but possesses a slightly different profile regarding its effects on intracellular dNTP concentrations in HT29 cells. Incubation with $4 \mu \mathrm{M}$ M8 caused a significant increase in intracellular dCTP and dTTP pools, whereas dATP pools were abolished. In particular, a similar depletion of dATP pool sizes was previously observed with Gemcitabine (27), a mechanism mainly contributing to the antitumor properties of this clinically established anticancer drug. The amount of dGTP remained beyond the detectability of the method.

Furthermore, a number of methoxylated RV analogs have recently been synthesized and tested, demonstrating the importance of a 3,5-dimethoxy motif in conferring proapoptotic activity to stilbene derivatives (28). The ability of pterostilbene and 3'-hydroxypterostilbene, natural 3,5dimethoxy analogs of RV and PCA, in terms of inducing apoptosis in sensitive and resistant leukemia cells were also evaluated (29). In addition, pterostilbene and 3'-hydroxypterostilbene, when used at concentrations that exhibit significant apoptotic effects in tumor cell lines, did not show any cytotoxicity in normal hemopoietic stem cells.

Of the methoxylated RV analogs prepared by our group, M5 (3,4',5-trimethoxy-trans-stilbene) and M5A (3,3',4,5'tetramethoxy-trans-stilbene) were evaluated in HT29 cells. Regarding the inhibition of tumor cell growth, M5 turned out to be much more potent than M5A, thereby underpinning the findings of Roberti and coworkers (28). The two compounds proved to be strong inducers of apoptosis, with M5 showing greater fractions of apoptotic cells at lower concentrations. Similarly, M5 and M5A caused significant cell cycle perturbations. M5 led to arrest mainly in the G2-M phase, while decreasing cells in the G0-G1 phase. In contrast, cell cycle arrest after treatment with M5A mainly occurred in the G0-G1 phase of the cell cycle, thereby decreasing cells in the G2-M phase.

Due to these promising results, the investigated RV analogs deserve further preclinical and in vivo testing.

\section{References}

1. Langcake P and Pryce RJ: The production of resveratrol by Vitis vinifera and other members of the Vitaceae as a response to infection or injury. Physiol Plant Pathol 9: 77-86, 1976.
2. Baur JA and Sinclair DA: Therapeutic potential of resveratrol: the in vivo evidence. Nat Rev Drug Discov 5: 493-506, 2006.

3. Dong Z: Molecular mechanism of the chemopreventive effect of resveratrol. Mutat Res 523-524: 145-150, 2003.

4. Hursting SD, Slaga TJ, Fischer SM, DiGiovanni J and Phang JM: Mechanism-based cancer prevention approaches: targets, examples, and the use of transgenic mice. J Natl Cancer Inst 91: 215-225, 1999.

5. Aggarwal BB and Shishodia S: Molecular targets of dietary agents for prevention and therapy of cancer. Biochem Pharmacol 71: 1397-1421, 2006.

6. Jang M, Cai L, Udeani GO, Slowing KV, Thomas CF, Beecher CW, Fong HH, Farnsworth NR, Kinghorn AD, Mehta RG, Moon RC and Pezzuto JM: Cancer chemopreventive activity of resveratrol, a natural product derived from grapes. Science 275: 218-220, 1997.

7. Stewart JR, Christman KL and O'Brian CA: Effects of resveratrol on the autophosphorylation of phorbol ester-responsive protein kinases: inhibition of protein kinase $\mathrm{D}$ but not protein kinase $\mathrm{C}$ isozyme autophosphorylation. Biochem Pharmacol 60: 1355-1359, 2000 .

8. Stewart JR, Ward NE, Ioannides CG and O'Brian CA: Resveratrol preferentially inhibits protein kinase C-catalyzed phosphorylation of a cofactor-independent, arginine-rich protein substrate by a novel mechanism. Biochemistry 38: 13244-13251, 1999.

9. Bhat KP, Lantvit D, Christov K, Mehta RG, Moon RC and Pezzuto JM: Estrogenic and antiestrogenic properties of resveratrol in mammary tumor models. Cancer Res 61: 7456-7463, 2001.

10. Gehm BD, McAndrews JM, Chien PY and Jameson JL: Resveratrol, a polyphenolic compound found in grapes and wine, is an agonist for the estrogen receptor. Proc Natl Acad Sci USA 94: 14138-14143, 1997.

11. Mitchell SH, Zhu W and Young CY: Resveratrol inhibits the expression and function of the androgen receptor in $\mathrm{LNCaP}$ prostate cancer cells. Cancer Res 59: 5892-5895, 1999.

12. Stojanovic S, Sprinz H and Brede O: Efficiency and mechanism of the antioxidant action of trans-resveratrol and its analogues in the radical liposome oxidation. Arch Biochem Biophys 391: 79-89, 2001

13. Elford HL, Freese M, Passamani E and Morris HP: Ribonucleotide reductase and cell proliferation. I. Variations of ribonucleotide reductase activity with tumor growth rate in a series of rat hepatomas. J Biol Chem 245: 5228-5233, 1970.

14. Fontecave M, Lepoivre M, Elleingand E, Gerez C and Guittet O: Resveratrol, a remarkable inhibitor of ribonucleotide reductase. FEBS Lett 421: 277-279, 1998.

15. Locatelli GA, Savio M, Forti L, Shevelev I, Ramadan K, Stivala LA, Vannini V, Hubscher U, Spadari S and Maga G: Inhibition of mammalian DNA polymerases by resveratrol: mechanism and structural determinants. Biochem J 389: 259-268, 2005.

16. Ragione FD, Cucciolla V, Borriello A, Pietra VD, Racioppi L, Soldati G, Manna C, Galletti P and Zappia V: Resveratrol arrests the cell division cycle at $\mathrm{S} / \mathrm{G} 2$ phase transition. Biochem Biophys Res Commun 250: 53-58, 1998.

17. Damianaki A, Bakogeorgou E, Kampa M, Notas G, Hatzoglou A, Panagiotou S, Gemetzi C, Kouroumalis E, Martin PM and Castanas E: Potent inhibitory action of red wine polyphenols on human breast cancer cells. J Cell Biochem 78: 429-441, 2000.

18. Gautam SC, Xu YX, Dumaguin M, Janakiraman N and Chapman RA: Resveratrol selectively inhibits leukemia cells: a prospective agent for ex vivo bone marrow purging. Bone Marrow Transplant 25: 639-645, 2000.

19. Pozo-Guisado E, Alvarez-Barrientos A, Mulero-Navarro S, Santiago-Josefat B and Fernandez-Salguero PM: The antiproliferative activity of resveratrol results in apoptosis in MCF-7 but not in MDA-MB-231 human breast cancer cells: cell-specific alteration of the cell cycle. Biochem Pharmacol 64: 1375-1386, 2002

20. Schneider Y, Vincent F, Duranton B, Badolo L, Gosse F, Bergmann C, Seiler N and Raul F: Anti-proliferative effect of resveratrol, a natural component of grapes and wine, on human colonic cancer cells. Cancer Lett 158: 85-91, 2000.

21. Zhou HB, Yan Y, Sun YN and Zhu JR: Resveratrol induces apoptosis in human esophageal carcinoma cells. World J Gastroenterol 9: 408-411, 2003.

22. Horvath Z, Saiko P, Illmer C, Madlener S, Hoechtl T, Bauer W, Erker T, Jaeger W, Fritzer-Szekeres $M$ and Szekeres T: Synergistic action of resveratrol, an ingredient of wine, with Ara-C and tiazofurin in HL-60 human promyelocytic leukemia cells. Exp Hematol 33: 329-335, 2005. 
23. Horvath Z, Murias M, Saiko P, Erker T, Handler N, Madlener S, Jaeger W, Grusch M, Fritzer-Szekeres M, Krupitza G and Szekeres T: Cytotoxic and biochemical effects of 3,3',4,4',5,5'hexahydroxystilbene, a novel resveratrol analog in HL-60 human promyelocytic leukemia cells. Exp Hematol 34: 1377-1384, 2006.

24. Murias M, Handler N, Erker T, Pleban K, Ecker G, Saiko P, Szekeres $\mathrm{T}$ and Jager W: Resveratrol analogues as selective cyclooxygenase- 2 inhibitors: synthesis and structure-activity relationship. Bioorg Med Chem 12: 5571-5578, 2004.

25. Grusch M, Polgar D, Gfatter S, Leuhuber K, Huettenbrenner S, Leisser C, Fuhrmann G, Kassie F, Steinkellner H, Smid K, Peters GJ, Jayaram HN, Klepal W, Szekeres T, Knasmuller S and Krupitza G: Maintenance of ATP favours apoptosis over necrosis triggered by benzamide riboside. Cell Death Differ 9: $169-178,2002$.

26. Garrett $\mathrm{C}$ and Santi DV: A rapid and sensitive high pressure liquid chromatography assay for deoxyribonucleoside triphosphates in cell extracts. Anal Biochem 99: 268-273, 1979.
27. Robinson BW, Im MM, Ljungman M, Praz F and Shewach DS: Enhanced radiosensitization with gemcitabine in mismatch repair-deficient HCT116 cells. Cancer Res 63: 6935-6941, 2003.

28. Roberti M, Pizzirani D, Simoni D, Rondanin R, Baruchello R, Bonora C, Buscemi F, Grimaudo S and Tolomeo M: Synthesis and biological evaluation of resveratrol and analogues as apoptosis-inducing agents. J Med Chem 46: 3546-3554, 2003.

29. Tolomeo M, Grimaudo S, Di Cristina A, Roberti M, Pizzirani D, Meli M, Dusonchet L, Gebbia N, Abbadessa V, Crosta L, Barucchello R, Grisolia G, Invidiata F and Simoni D: Pterostilbene and 3'-hydroxypterostilbene are effective apoptosisinducing agents in MDR and BCR-ABL-expressing leukemia cells. Int J Biochem Cell Biol 37: 1709-1726, 2005. 